\title{
Metabolism of Dehydroepiandrosterone Sulfate and Estrone-Sulfate by Human Platelets
}

\author{
A. GARRIDO ${ }^{1}$, Y. MUÑOZ ${ }^{1}$, W. SIERRALTA ${ }^{1}$, L. VALLADARES $^{1}$ \\ ${ }^{1}$ Institute of Nutrition and Food Technology, Universidad de Chile, Santiago, Chile
}

Received January 20, 2012

Accepted April 20, 2012

On-line June 6, 2012

\section{Summary}

The aim of the present research was to study the uptake of DHEAS, and to establish the intracrine capacity of human platelets to produce sex steroid hormones. The DHEAS transport was evaluated through the uptake of $\left[{ }^{3} \mathrm{H}\right]$-DHEAS in the presence or absence of different substrates through the organic anion transporting polypeptide (OATP) family. The activity of sulfatase enzyme was evaluated, and the metabolism of DHEAS was measured by the conversion of $\left[{ }^{3} \mathrm{H}\right]$-DHEAS to $\left[{ }^{3} \mathrm{H}\right]$-androstenedione, $\left[{ }^{3} \mathrm{H}\right]$-testosterone, $\left[{ }^{3} \mathrm{H}\right]$-estrone and $\left[{ }^{3} \mathrm{H}\right]-17 \beta$-estradiol. Results indicated the existence in the plasma membrane of an OATP with high affinity for DHEAS and estrone sulphate $\left(E_{1} S\right)$. The platelets showed the capacity to convert DHEAS to active DHEA by the steroid-sulfatase activity. The cells resulted to be a potential site for androgens production, since they have the capacity to produce androstenedione and testosterone; in addition, they reduced $\left[{ }^{3} \mathrm{H}\right]$-estrone to $\left[{ }^{3} \mathrm{H}\right]-17 \beta$ estradiol. This is the first demonstration that human platelets are able to import DHEAS and $E_{1} S$ using the OATP family and to convert DHEAS to active DHEA, and to transform $E_{1} S$ to $17 \beta$ estradiol.

\section{Key words}

Platelet $\bullet$ Intracrine $\bullet$ Steroid sulfatase $\bullet$ DHEAS

\section{Corresponding author}

L. Valladares, El Libano 5524, Santiago 11, Chile. Fax: 56-22214030. E-mail: Ivallada@inta.cl

\section{Introduction}

Platelets play a crucial role in the development of arterial thrombosis and other pathophysiologies leading to clinical ischemic events. In human, the incidence of adverse thrombotic events increases with age, and many studies suggest that low sex steroids hormones level accelerates age-related pathogenic changes in vascular and haemostatic systems (Wilkerson et al. 2002). In women, at menopause the deficiency of sex steroids hormones accelerates age-related pathogenic changes in vascular and haemostatic systems.

The effect of sex hormone on platelet function has been investigated for years, but conflicting results have been reported. Treatment of platelets with estrogen in vitro has not always produced results consistent with estrogens in vivo prothrombotic activity. One variable that confounds in vitro assays of platelet aggregation is the intrinsic effect of endogenous estrogens within platelets (Leng and Bray 2005). Some studies show that there are significant differences in the concentration of $17 \beta$-estradiol between the inside and outside of platelets (Nakano et al. 1998, Sarabia et al. 2008). The ratio of platelet to plasma estradiol concentrations in men, premenopausal and postmenopausal women was 7.0, 2.8 and 5.3 fmol per platelet $\mathrm{x} 10^{9} / \mathrm{pmol}^{-1}$ plasma, respectively. The mechanism by which the internal concentration is increased had not been clarified; it has been suggested that some transport exist in platelet to increase the levels of sex hormones in the intraplatelet pool (Sarabia et al. 2008). Nevertheless, similar to what it happens in peripheral tissue, the platelets might synthesize steroids hormones.

Human, along with other primates, are unique among animal species in having adrenals that secrete 
large amounts of precursor steroids like dehydroepiandrosterone (DHEA) and especially DHEAsulfate (DHEAS). The plasma levels of DHEA in human are 100 to 500 times higher than testosterone and 1,000 to 10,000 higher than estradiol (Labrie et al. 2005). DHEA can be converted downstream to sex steroids, thereby having its role as a precursor for human sex steroid biosynthesis (Labrie et al. 2005). Many report have shown evidences that DHEA/DHEAS could play a protective role in the pathogenesis of atherosclerosis and coronary heart disease (Porsova-Dutoit et al. 2000, Triveli et al. 2001). However, the mechanism of action of these steroids is not clear. Peripherally, DHEA appears to exert its primary effect through its estrogenic and androgenic metabolites because a unique DHEA receptor has not been characterized (Susan et al. 2012). The direction of conversion of DHEA defines its biological action in target tissues and depends on the tissue-specific expression of the steroidogenic enzymes. This system illustrates the concept of intracrinology involving activation, action, and metabolism of steroids within one and the same peripheral target cell (Labrie et al. 2001).

While DHEA is highly hydrophobic, DHEAS is hydrophilic and requires active transport to enter the cell. Many studies in human tissues have implicated several members of the organic anion transport polypeptide (OATP) family as responsible for DHEAS influx transport (Hagenbuch and Meir 2003, Ugele et al. 2003). Once in the cell, DHEAS may be activated to DHEA following hydrolysis of sulfate group by the microsomal enzyme steroid sulfatase (STS) (Reed et al. 2005). Vice versa, DHEA can be inactivated via sulfonation to DHEAS by cytosolic DHEA sulfotransferase. Thus, tissue-specific expression and activity of the components of this "DHEAS/DHEA shuttle" system will determine intracellular bioavailability of DHEA.

There are experimental evidences showing human platelets involvement in steroid-metabolism; for instance, they can convert androstenedione to potent androgens (Milewich and Whisenant 1982). Also, human platelets are a site of estrogens production since they are able to convert estrone sulfate to estrone (Soliman et al. 1993). However, it has not been investigated whether platelet cells are sites of conversion of DHEAS to DHEA, a potential precursor for the synthesis of steroids. In addition, it is not clear whether they possess aromatase activity required for the conversion of androgens into estrogens. This study aimed to determine the uptake of DHEAS, and to establish the intracrine capacity of human platelets to produce sex steroid hormones.

\section{Materials and Methods}

\section{Steroids and chemical}

For the enzyme assays, we used $\left[1,2,6,7-{ }^{3} \mathrm{H}\right]-$ dehydroepiandrosterone-sulphate $(84 \mathrm{Ci} / \mathrm{mmol}),[1,2,6,7-$ $\left.{ }^{3} \mathrm{H}\right]$-DHEA (74 Ci/mmol), $\left[1 \beta-{ }^{3} \mathrm{H}\right]$-androstenedione $(24.3$ $\mathrm{Ci} / \mathrm{mmol}),\left[6,7-{ }^{3} \mathrm{H}\right]$-estrone-sulfate $(43.5 \mathrm{Ci} / \mathrm{mmol})$, all obtained from Perkin-Elmer Life Science (Boston, MA). Unlabeled steroids were purchased from Sigma-Aldrich. The bromosulfophthalein (BSP) from ApplichemGermany; all other chemicals and solvents were from Merck (Darmstadt, Germany).

\section{Isolation of human platelets}

Platelet-rich plasma (PRP) was prepared by differential centrifugation $\left(180 \mathrm{x} \mathrm{g}, 15 \mathrm{~min}, 23^{\circ} \mathrm{C}\right)$ of fresh whole human blood drawn into acid-citrate anticoagulant $(1: 9 \mathrm{v} / \mathrm{v})$. The PRP-derived platelet concentrates (PCs) were obtained by centrifugation at $1000 \mathrm{x} \mathrm{g}$ for $10 \mathrm{~min}$ at $20^{\circ} \mathrm{C}$. The freshly prepared PCs were washed free of plasma components twice with $\mathrm{Ca}^{2+}$ free Tyrode's buffer (137 mM NaCl, $2.9 \mathrm{mM} \mathrm{KCl}$, $12 \mathrm{mM} \mathrm{NaHCO} 3,0.42 \mathrm{mM} \mathrm{Na} \mathrm{HPO}_{4}, 5 \mathrm{mM}$ HEPES, $2 \mathrm{mM} \mathrm{MgCl} 2$ and $5.5 \mathrm{mM}$ glucose $\mathrm{pH} 7.4$ ), according to the method described by Mustard et al. (1972). Washed platelets were resuspended in Tyrode's buffer and platelet concentrations were determined electronically with Coulter counter and adjusted to $\sim 5 \times 10^{8}$ platelets $/ \mathrm{ml}$.

\section{DHEAS transport in platelets}

Washed platelets $\left(3 \times 10^{8}\right)$ were resuspended in $1 \mathrm{ml}$ of uptake buffer (Tyrode's buffer containing $\left[{ }^{3} \mathrm{H}\right]$-DHEAS). Then, platelets were incubated at various periods of time with constant shaking at $37{ }^{\circ} \mathrm{C}$, and the uptake was terminated by addition of $1 \mathrm{ml}$ of ice-cold Tyrode's buffer followed by rapid filtration under reduced pressure through Whatman GFC glass fibber filters pre-washed with uptake buffer. The filters were rapidly washed with cold assay buffer (3 times, $1 \mathrm{ml}$ each). The cell-associated radioactivity was determined by transferring the dried filters to scintillation vials and measuring radioactivity by liquid scintillation.

For inhibition studies, uptake of $\left[{ }^{3} \mathrm{H}\right]$-DHEAS was measured in the presence of unlabeled compounds such as sulfobromophthalein (BSP; 0-50 $\mu \mathrm{mol} / \mathrm{l}$ ), a specific inhibitor of the OATP family, or in the presence of an excess of estrone sulfate $(50 \mu \mathrm{mol} / \mathrm{l})$ or DHEAS 
( $50 \mu \mathrm{mol} / \mathrm{l})$; the samples were incubated at $37^{\circ} \mathrm{C}$ for $5 \mathrm{~min}$.

\section{Assay of sulfatase activity}

The activity of STS was measured according to the method of Steckelbroeck et al. (2004). In brief, in a final volume of $200 \mu \mathrm{l}$, aliquots of platelets $\left(\sim 1.5 \times 10^{8}\right.$ platelets) were incubated at $37{ }^{\circ} \mathrm{C}$ with $0.5 \mu \mathrm{M}$ DHEAS and $300,000 \mathrm{dpm}$ of $\left[{ }^{3} \mathrm{H}\right]$-DHEAS for different times, with constant shaking. The reaction was terminated by adding 2 volumes of $0.1 \mathrm{~N} \mathrm{NaOH}$, and DHEA was extracted with $3 \mathrm{ml}$ of toluene. The radioactivity in the toluene extract was measured in a $0.5 \mathrm{ml}$ aliquot with a liquid scintillation counter. Spontaneous DHEAS conversion and background radioactivity were subtracted from each experimental assay tube. The metabolite was identified by TLC-silica gel using the system tolueneethanol-water (90:9.5:0.5) and appropriate standard (Wong and Keung 1997).

\section{Metabolism of $\left[{ }^{3} H\right]-D H E A S$}

Platelets (2-3 x $10^{8}$ platelet) were incubated for $3 \mathrm{~h}$ at $37^{\circ} \mathrm{C}$ in $0.2 \mathrm{ml}$ Tyrode's buffer containing $0.5 \mu \mathrm{M}$ DHEAS and $4 \times 10^{5} \mathrm{dpm}$ of $\left[{ }^{3} \mathrm{H}\right]$-DHEAS. At the end of the incubation period, $50 \mu \mathrm{g}$ of the nonradioactive carrier steroids androstenedione (A), testosterone ( $\mathrm{T})$, estradiol $\left(E_{2}\right)$ and estrone $\left(E_{1}\right)$ were added to each sample. The reaction was stopped with $1.5 \mathrm{ml}$ of acetone-ethyl acetate $(1: 2.5 ; \mathrm{v} / \mathrm{v})$ and the organic supernatant layer was removed. A portion $(1 \mathrm{ml})$ of the extract was evaporated to dryness, and the residue were then dissolved in $100 \mu \mathrm{l}$ of dichloromethane and the yield of metabolites measured after separation by chromatography,

The steroids in the extract were separated by TLC on silica gel using xylene- ethylacetate-cloroform $(40: 15: 45, \mathrm{v} / \mathrm{v})$ which gives good separation of $\mathrm{T}, \mathrm{A}$ and $\mathrm{E}_{1}$ (Rf: 0.26, 0.55 and 0.79, respectively; $\mathrm{Rf}$ is the distance traveled by the compound divided by the distance traveled by the solvent). The localization of steroids were visualized and identified by their chromogenic properties after spraying with $5 \%(\mathrm{v} / \mathrm{v})$ sulphuric acid in methanol and heating on a hot plate (Heftmann et al. 1996).

Control incubations containing $\left[{ }^{3} \mathrm{H}\right]$-DHEAS in Tyrode's buffer but without platelets, were processed in a similar manner.

\section{Metabolism $[3 \mathrm{H}]$-estrone-sulfate}

Platelets $\left(2-3 \times 10^{8}\right.$ platelet $)$ were incubated for
$3 \mathrm{~h}$ at $37{ }^{\circ} \mathrm{C}$ in $0.2 \mathrm{ml}$ Tyrode's buffer containing $0.5 \mu \mathrm{M}$ $\mathrm{E}_{1} \mathrm{~S}$ and $5 \times 10^{5} \mathrm{dpm}$ of $\left[{ }^{3} \mathrm{H}\right]-\mathrm{E}_{1} \mathrm{~S}$. At the end of the incubation period, $50 \mu \mathrm{g}$ of the nonradioactive carrier steroid $E_{1}$ and $E_{2}$ were added to each sample. The reaction was stopped with $2 \mathrm{ml}$ of ether and the organic supernatant layer was removed. A portion $(1.5 \mathrm{ml})$ of the extract was evaporated to dryness, and the residue dissolved in $100 \mu \mathrm{l}$ of acetonitrile-water (45:55, v/v) and further separated on Sephasil $C$ reverse-phase chromatography column connected Merck-Hitachi System. Fractions containing estrone and 17 $\beta$-estradiol were dissolved in scintillation liquid and radioactivities were measured.

\section{Aromatase activity assay}

Aromatase activity was quantified by the stereospecific loss of the tritium atom of the $\left[1 \beta-{ }^{3} \mathrm{H}\right]$ androstenedione substrate in the aromatization reaction. The conversion rate was determined by the isolation and quantification of tritiated water (Lephart et al. 1991). Aliquots of washed platelets $\left(0.5-2 \times 10^{8}\right.$ platelets) were incubated with $200 \mathrm{nM}\left[1-{ }^{3} \mathrm{H}\right]-$ androstenedione to make a final volume of $200 \mu \mathrm{l}$. A portion of the aqueous phase was mixed with an equal volume of $5 \%$ charcoal- $0.5 \%$ dextran suspension, centrifuged for $30 \mathrm{~min}$ at $2000 \mathrm{x} \mathrm{g}$, and quantified by liquid scintillation counting. Background values for ${ }^{3} \mathrm{H}_{2} \mathrm{O}$ released in the absence of cells were subtracted from each point.

\section{Statistical analyses}

Data are expressed as means \pm S.D. The significance of differences between the mean values was determinate by Student's $t$ test, and a $p$ value of less than 0.05 was considered statistically significant.

\section{Results}

\section{DHEAS transporters assay}

This assay was performed to investigate whether DHEAS transport is OATP-mediated in these cells. Then, the cis-inhibitory effect of a variety of non-radioactive conjugated steroids and OATP substrates on DHEAS uptake was examined.

We first incubated the platelets with $\left[{ }^{3} \mathrm{H}\right]-$ DHEAS at increasing OATP-specific substrate concentrations BSP $(0-50 \mu \mathrm{mol} / 1)$ over a period of $5 \mathrm{~min}$. As shown in Figure 1, the uptake revealed a decreased response with increased concentrations of BSP. 


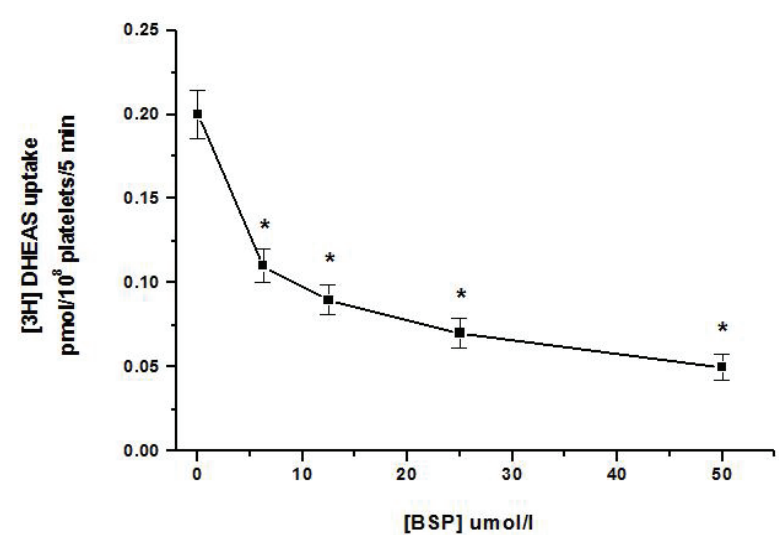

Fig. 1. Human platelets DHEAS uptake: Inhibitory effect of sulfobromophthalein (BSP). The uptake was measured after 5 minutes of platelets incubation with $\left[{ }^{3} \mathrm{H}\right]-$ DHEAS in the presence of increasing concentrations of BSP $(0-50 \mu \mathrm{mol} / \mathrm{l})$. Data represent the mean \pm S.D. for three experiments. $* \mathrm{P}<0.05$ compared with control without BSP.

We also examine the substrate selectivity of the transport system. The uptake of $\left[{ }^{3} \mathrm{H}\right]$-DHEAS was strongly inhibited by common OATP substrates, BSP $(50 \mu \mathrm{mol} / \mathrm{l})$, DHEAS $(50 \mu \mathrm{mol} / \mathrm{l})$ and estrone sulfate (50 $\mu \mathrm{mol} / 1)(\%$ of control; Fig. 2$)$.

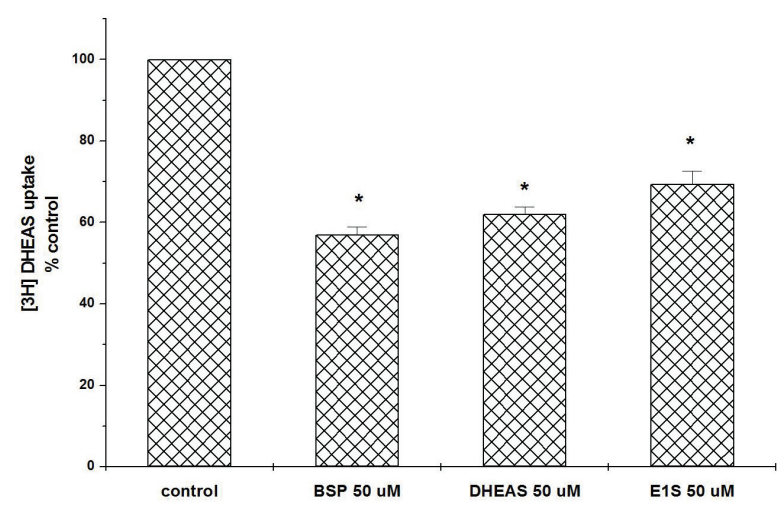

Fig. 2. The substrate selectivity of OATP system in human platelets. The uptake was measured after 5 minutes of platelets incubation with $\left[{ }^{3} \mathrm{H}\right]$-DHEAS in the presence of BPS $(50 \mu \mathrm{mol} / \mathrm{l})$, DHEAS $(50 \mu \mathrm{mol} / \mathrm{l})$ or estrone sulfate $(50 \mu \mathrm{mol} / \mathrm{l})$. Data represent the mean \pm S.D. for three experiments. $* \mathrm{P}<0.05$ compared control.

As described, estradiol- $\beta$-glucuronide is not a substrate of OATPB, and therefore is not able to be transported into the cells; in the present study we evaluated the uptake of $\left[{ }^{3} \mathrm{H}\right]$-estradiol- $\beta$-glucuronide in human platelets. No uptake of this labelled steroid was observed $\left(100 \pm 6.4 \%\right.$ control $\quad$ vs. $\quad 98.2 \pm 8.7 \% \quad\left[{ }^{3} \mathrm{H}\right]$-estradiol- $\beta$ glucuronide), indicating that the OATP present en human platelets have the characteristics of OATPB.

\section{Conversion of DHEAS to DHEA in human platelets}

Platelets contain aryl sulfatase activity, as indicated by the conversion of $\left[{ }^{3} \mathrm{H}\right]$-DHEAS to $\left[{ }^{3} \mathrm{H}\right]$-DHEA in the order of $9.6 \pm 0.54 \mathrm{pmol} / \mathrm{h} \cdot 10^{8}$ platelets. There was a linear relationship between the amount of DHEA produced and platelet concentration up to $3.0 \times 10^{8}$ platelets (data not-shown), and the hydrolysis of $\left[{ }^{3} \mathrm{H}\right]$-DHEAS was observed to proceed linearly with incubation times up to $3 \mathrm{~h}$ (Fig. 3).

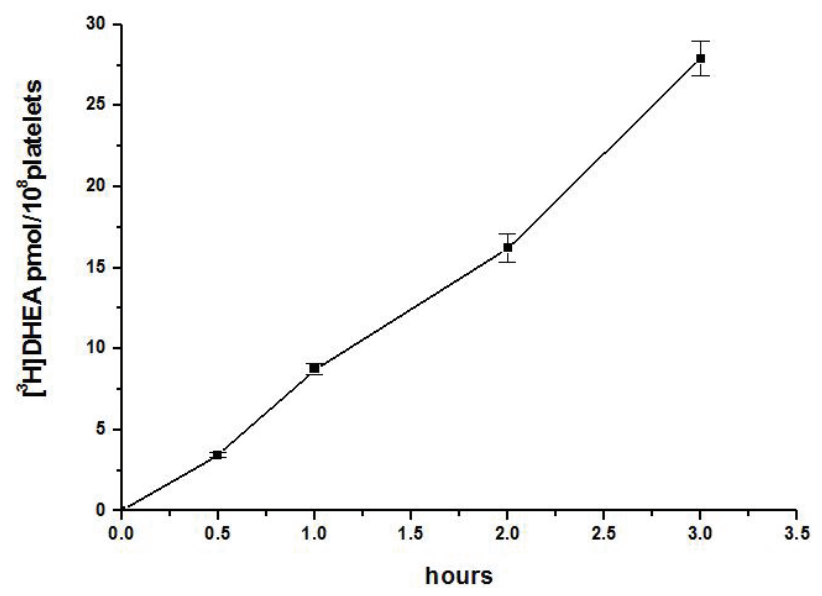

Fig. 3. Sulfatase activity through the production of $\left[{ }^{3} \mathrm{H}\right]$-DHEA from $\left[{ }^{3} \mathrm{H}\right]$-DHEAS by human platelets. Aliquot of platelets $(\sim 1.5$ x $10^{8}$ platelets) were incubated with $0.5 \mu \mathrm{M}$ and $300,000 \mathrm{dpm}$ of $\left[{ }^{3} \mathrm{H}\right]$-DHEAS for different times at $\mathrm{pH} 7.4$ and $37^{\circ} \mathrm{C}$. Data represent the mean \pm S.D. ( $n=4$ experiments).

\section{Metabolism of [ $\left.{ }^{3} H\right]-D H E A S$}

By adding $\left[{ }^{3} \mathrm{H}\right]$-DHEAS to platelets, we sought to investigate whether human platelets are capable of using DHEAH as a substrate for local steroidogenesis. The metabolites produced per $10^{8}$ platelets $(n=3)$ in $3 \mathrm{~h}$ incubation were identified as androstenedione $(3.3 \pm 0.8$ pmol) and testosterone $(2.1 \pm 0.5 \mathrm{pmol})$.

\section{Aromatase activity assay}

The potential capacity of human platelets to produce estrogens was assessed by the incorporation of tritium from $\left[1-{ }^{3} \mathrm{H}\right]$-androstenedione into $\left[{ }^{3} \mathrm{H}\right]$-water. In the presence or absence of platelet the radioactivity of $\left.{ }^{3} \mathrm{H}\right]$-water was $430 \pm 40 \mathrm{dpm} / \mathrm{h} \cdot 10^{8}$ platelets and $590 \pm 210$ $\mathrm{dpm} / \mathrm{h} \bullet$ incubated, respectively. This value represents the mean \pm S.D. of six independent determinations. In the presence of a specific nonsteroidal aromatase inhibitor (letrozole, $10 \mu \mathrm{M}$ ), the incorporation of radioactivity into $\left[{ }^{3} \mathrm{H}\right]$-water was not affected; $465 \pm 51 \mathrm{dpm} / \mathrm{h} \cdot 10^{8}$ platelets in the control versus $446 \pm 39 \mathrm{dpm} / \mathrm{h} \cdot 10^{8}$ platelets in the presence of letrozole. 


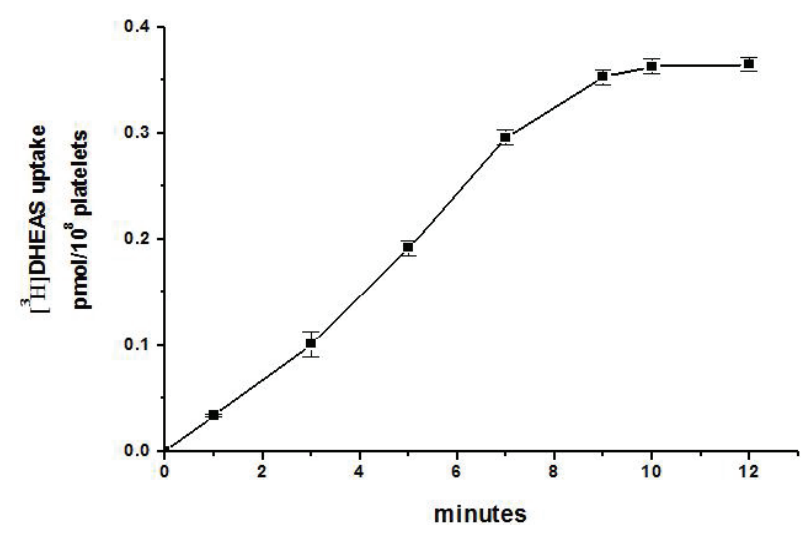

Fig. 4. Time course of the uptake of $\left[{ }^{3} \mathrm{H}\right]$-DHEAS by human platelets. Uptake of $\left[^{3} \mathrm{H}\right]$-DHEAS over 10 minutes was measured at $37^{\circ} \mathrm{C}$ in the Tyrode's buffer at pH 7.4. Each result represent the mean \pm S.D. ( $n=7$ experiments).

\section{Conversion of $\left[{ }^{3} H\right]-E_{1} S$ to estradiol}

The role of $\mathrm{E}_{1} \mathrm{~S}$ as precursor of estradiol in platelets was analyzed. An amount of $10^{8}$ platelets produced in $3 \mathrm{~h}$ incubation $3.1 \pm 0.7$ pmol $17 \beta$-estradiol $(n=4)$.

\section{Transport of DHEAS}

To analyze the transport of DHEAS in human platelets, we evaluated the uptake of $\left[{ }^{3} \mathrm{H}\right]$-DHEAS for different periods of time (0-12 $\mathrm{min})$. We observed that $\left[\mathrm{H}^{3}\right]$-DHEAS uptake increased linearly for $7 \mathrm{~min}$ and reached a steady state between 9 and 12 min (Fig. 4). The initial rate for the uptake of DHEAS concentrations $(0.0012 \mu \mathrm{M}$ to $0.74 \mu \mathrm{M})$ was then determined (Fig. 5). Kinetic analysis revealed a saturable uptake mechanism.

\section{Discussion}

Circulating blood platelets are anucleated cells that retain small amounts of megacaryocyte $\mathrm{mRNA}_{(\mathrm{s})}$ and fully functional proteins (Gnatenko et al. 2003, McRedmond et al. 2004). The main interest of the present study was to investigate platelet STS in the context of DHEAS carrier, as well the possible de novo biosynthesis of androgens and estrogens. The results of our studies confirm that STS and DHEA metabolizing enzymes are present in human platelets (Soliman et al. 1993). Additionally, our data demonstrate strong interaction of organic anionic polypeptide transporters (OATP)mediated uptake of DHEAS and estrone-sulfate.

Although circulating blood platelets import a variety of free and conjugate steroids, the most important precursor appears to be DHEAS, which circulates at much higher concentration than free DHEA, gonadal

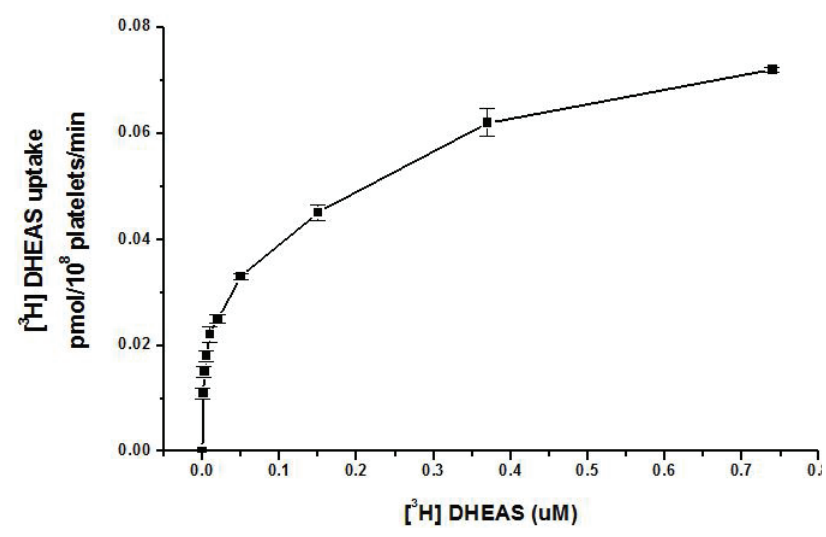

Fig. 5. Concentration dependence of $\left[{ }^{3} \mathrm{H}\right]-\mathrm{DHEAS}$ uptake by human platelets. The uptake of $\left[{ }^{3} \mathrm{H}\right]$-DHEAS was measured after 5 minutes of platelet incubation with various concentrations of $\left[{ }^{3} \mathrm{H}\right]$-DHEAS from $1.2 \mathrm{nM}$ to $0.8 \mu \mathrm{M}$ at $\mathrm{pH}$ 7.4. Data represent the mean \pm S.D. $(n=4)$.

steroids, and cortisol (Labrie et al. 2001). We did not characterize the transporter; however, our results clearly indicate the existence in the membrane of platelets of an OATP with high affinity for DHEAS and estrone sulfate. Supporting evidences for the presence of such transport system include 1) a saturable uptake kinetics, 2) significant time dependence for the uptake of DHEAS, and 3) inhibition of the uptake in the presence of structural analogs. The fact that no uptake of estradiol$17 \beta$-glucuronide by human platelets was observed, suggest that DHEAS OATP of human platelets have the characteristic of OATPB (Tamai et al. 2001). This type of transporters are present in a broad range of tissues, where OATP2B1 is the predominant mediator of DHEAS (Kullak-Ublick et al. 2001, Pizzagalli et al. 2003). Interestingly, it has been recently demonstrated that human platelets express high abundance of OATP2B1, but not OATP1B1 (Niessen et al. 2009).

Platelet STS enzyme appears to be membrane bound. Mammalian sulfatases have been shown to be lysosomal (arylsulfatases A and B) or microsomal (arysulfatase C), demonstrating acidic or alkaline optimal $\mathrm{pH}$ for their activity, respectively. This enzyme has also been found in different tissues (Miki et al. 2002, Reed et al. 2005), including leucocytes (Purohit et al. 1997) and platelets (Soliman et al. 1993, Kirk et al. 2001).

The presence of steroidogenic functional enzymes in platelets is strongly support by their capacity to convert $\left[{ }^{3} \mathrm{H}\right]$-DHEAS into $\left[{ }^{3} \mathrm{H}\right]$-androstenedione, and $\left[{ }^{3} \mathrm{H}\right]$-testosterone. Consequently, platelets must have the enzyme $3 \beta$-hydroxysteroid dehydrogenase type 1 , as indicated by the formation of androstenedione, and 17ß-hydrosteroid dehydrogenase (type 3), demonstrated 
by the formation of testosterone. As mentioned before, Milewich and Whisenant (1982) previously reported on the metabolism of androstenedione by human platelets. More recently, evidence was presented showing that distinct subtypes of the steroidogenic 17 $\beta$-HSD enzymes are functionally expressed in human platelets (Gnatenko et al. 2005). We did not detect production of $\left[{ }^{3} \mathrm{H}\right]$-estradiol or $\left[{ }^{3} \mathrm{H}\right]$-estrone from $\left[{ }^{3} \mathrm{H}\right]$-DHEA, and, furthermore, no release of ${ }^{3} \mathrm{H}_{2} \mathrm{O}$ from $\left[1 \beta-{ }^{3} \mathrm{H}\right]-$ androstenedione was found, thus discarding the presence of aromatase in platelets. However, platelets have the capacity to produce estradiol by reduction of estrone.

The biological activity of sex steroid hormones occurs predominantly through binding to the intracellular steroid receptors. Human platelets express both androgen and estrogen receptors (Nealen et al. 2001, Jayachandran and Miller 2003), but the physiological significance of steroid hormones in their function is under debate. An important point of controversy is related to concentrations of hormone that affect platelets activation. Recently, has been demonstrated that estradiol inhibits collageninduced platelet aggregation (Wu et al. 2010); concentration of estradiol at which effect were observed (5 $\left.\times 10^{-6}-10^{-5} \mathrm{~mol} / \mathrm{l}\right)$ were higher that its physiological circulating level (typically $10^{-8}$ to $10^{-9} \mathrm{~mol} / \mathrm{l}$ ). The fact that such pharmacological levels of estradiol were required to inhibit platelet aggregation, suggest that intraplatelet concentration of estradiol are different from blood estradiol. Interestingly, it has been observed that the internal platelet sex hormone levels are significantly higher that concentrations of androgens and estrogens in plasma (Sarabia et al. 2008). The mechanism by which intra-platelet steroid concentration is increased is not clear but it has suggested that a transport system exist in platelets (Chu et al. 2010). However, similar to what it happens in peripheral tissues the platelet may synthesize testosterone and estrogen.

Several studies suggest that DHEAS is a protective factor against atherosclerosis and coronary artery disease in humans, but the mechanisms involved in its biological role are not clear. DHEA administration induce vasodilatation (Williams et al. 2004), increases platelets cGMP production (Martina et al. 2006), inhibit smooth cell proliferation (Dworkin et al. 1986), and PAI-1 production (Beer et al. 1996). The in vivo and in vitro study of Jesse et al. (1995) demonstrated that DHEAS inhibits human platelets aggregation; importantly, in their study, it was hypothesized that DHEAS either directly inhibits platelets aggregation or that its hydrolysis occurred at the platelet surface, producing DHEA as the active steroid. Recently, it has been reported that DHEAS, but not DHEA, inhibits the in vitro aggregation of platelets stimulated with various agonist including thrombin, collagen and analogous of thromboxane $\mathrm{A}_{2}$ (Bertoli et al. 2012).

In conclusion, taken together the above evidence and our results, for one side DHEAS/DHEA can modulate platelet function by exercising an antiaggregating role, and for other side, the platelets can use DHEAS/DHEA or $\mathrm{E}_{1} \mathrm{~S} / \mathrm{E}_{1}$ as precursor of androgen and estrogen. The intracrine capacity of platelets indicate novel insights into the interplay between DHEAS/DHEA, platelet function and vascular disease.

\section{Conflict of Interest}

There is no conflict of interest.

\section{Acknowledgements}

Supported by FONDECYT 1100299.

\section{References}

BEER NA, JAKUBOWICZ DJ, MATT DW, BEER RM, NESTLER JE: Dehydroepiandrosterone reduces plasma plasminogen activator inhibitor type 1 and tissue plasminogen activator antigen in men. Am J Med Sci 311: 205-210, 1996.

BERTONI A, RASTOLDO A, SARASSO C, Di VITO C, SAMPIETRO S, NALIN M, BAGAROTTI A, SINIGAGLIA F: Dehydroepiandrosterone-sulfate inhibits thrombin-induced platelet aggregation. Steroids 77 : 260-268, 2012.

CHU SG, BECKER RC, BERGER PB, BHATT DL, EIKELBOOM JW, KONKLE B, MOHLER ER, REILLY MP, BERGER JS: Mean platelet volume as a predictor of cardiovascular risk: a systematic review and metaanalysis. J Thromb Haemost 8: 148-156, 2010. 
DWORKIN CR, GORMAN SD, PASHKO LL, CRISTOFALO VJ, SCHWARTZ AG: Inhibition of growth of HeLa and WI-38 cells by dehydroepiandrosterone and its reversal by ribo- and deoxyribonucleosides. Life Sci 38: 451-1457, 1986.

GNATENKO DV, CUPIT LD, HUANG EC, DHUNDALE A, PERROTTA PL, BAHOU WF: Platelets express steroidogenic 17beta-hydroxysteroid dehydrogenases. Distinct profiles predict the essential thrombocythemic phenotype. Thromb Haemost 94: 412-421, 2005.

GNATENKO DV, DUNN JJ, MCCORKLE SR, WEISSMANN D, PERROTTA PL, BAHOU WF: Transcript profiling of human platelets using microarray and serial analysis of gene expression. Blood 10: 12285-12293, 2003.

HAGENBUCH B, MEIER PJ: The superfamily of organic anion transporting polypeptides. Biochim Biophys Acta 10: $1-18,2003$.

HEFTMANN E, KO ST, BENNETT RD: Response of steroid to sulphuric acid in thin-layer chromatography. J Chromatogr 21: 490-494, 1996.

JAYACHANDRAN M, MILLER VM: Human platelets contain estrogen receptor alpha, caveolin-1 and estrogen receptor associated proteins. Platelets 14: 75-81, 2003.

JESSE RL, LOESSER K, EICH DM, QIAN YZ, HESS ML, NESTLER JE: Dehydroepiandrosterone inhibits human platelet aggregation in vitro and in vivo. Ann NY Acad Sci 774: 281-290, 1995.

KIRK CJ, HARRIS RM, WOOD DM, WARING RH, HUGHES PJ: Do dietary phytoestrogens influence susceptibility to hormone-dependent cancer by disrupting the metabolism of endogenous oestrogens? Biochem Soc Trans 29: 209-216, 2001.

KULLAK-UBLICK GA, ISMAIR MG, STIEGER B, LANDMANN L, HUBER R, PIZZAGALLI F, FATTINGER K, MEIER PJ, HAGENBUCH B: Organic anion-transporting polypeptide B (OATP-B) and its functional comparison with three other OATPs of human liver. Gastroenterology 120: 525-533, 2001.

LABRIE F, LUU-THE V, BÉLANGER A, LIN SX, SIMARD J, PELLETIER G, LABRIE C: Is dehydroepiandrosterone a hormone? J Endocrinol 187: 169-196, 2005.

LABRIE F, LUU-THE V, LABRIE C, SIMARD J: DHEA and its transformation into androgens and estrogens in peripheral target tissues: intracrinology. Front Neuroendocrinol 22: 185-212, 2001.

LENG X-H, BRAY PF: Hormone therapy and platelet function. Drug Discov Today 2: 85-91, 2005.

LEPHART ED, SIMPSON ER: Assay of aromatase activity. Meth Enzymol 206: 477-483, 1991.

MARTINA V, BENSO A, GIGLIARDI VR, MASHA A, ORIGLIA C, GRANATA R, GHIGO E: Short-term dehydroepiandrosterone treatment increases platelet cGMP production in elderly male subjects. Clin Endocrinol (Oxf) 64: 260-64, 2006.

MCREDMOND JP, PARK SD, REILLY DF, COPPINGER JA, MAGUIRE PB, SHIELDS DC, FITZGERALD DJ: Integration of proteomics and genomics in platelets: a profile of platelet proteins and platelet-specific genes. Mol Cell Proteomics 3: 133-144, 2004.

MIKI Y, NAKATA T, SUZUKI T, DARNEL AD, MORIYA T, KANEKO CH, HIDAKA K, SHIOTSU Y, KUSAKA H, SASANO H: Systemic distribution of steroid sulfatase and estrogen sulfotransferase in human adult and fetal tissues. J Clin Endocrinol Metab 87: 5760-5768, 2002.

MILEWICH L, WHISENANT MG: Metabolism of androstenedione by human platelets: a source of potent androgens. J Clin Endocrinol Metab 54: 969-974, 1982.

MUSTARDS JF, PERRY DW, ARDLIE NG, PACKAM MA: Preparation of suspension of washed platelet from human. Br J Haematol 22: 193-204, 1972.

NEALEN ML, VIJAYAN KV, BOLTON E, BRAY PF: Human platelets contain a glycosylated estrogen receptor beta. Circ Res 88: 438-442, 2001.

NAKANO Y, OSHIMA T, MATSUURA H, KAJIYAMA G, KAMBE M: Effect of 17ß-estradiol on inhibition of platelet aggregation in vitro is mediated by an increase in NO synthesis. Arterioscler Thromb Vasc Biol 18: 961-967, 1998.

NIESSEN J, JEDLITSCHKY G, GRUBE M, BIEN S, SCHWERTZ H, OHTSUKI S, KAWAKAMI H, KAMIIE J, OSWALD S, STARKE K, STROBEL U, SIEGMUND W, ROSSKOPF D, GREINACHER A, TERASAKI T, KROEMER HK: In human platelets express OATP2B1, an uptake transporter for atorvastatin. Drug Metab Dispos 37: 1129-1137, 2009. 
PIZZAGALLI F, VARGA Z, HUBER D, FOLKERS G, MEIER PJ, ST-PIERRE MV: Identification of steroid sulfate transport processes in the human mammary gland. J Clin Endocrinol Metab 88: 3902-3912, 2003.

PORSOVÁ-DUTOIT I, SULCOVÁ J, STÁRKA L: Do DHEA/DHEAS play a protective role in coronary heart disease? Physiol Res 49 (Suppl 1): S43-S56, 2000.

PUROHIT A, FROOME VA, WANG DY, POTTER BV, REED MJ: Measurement of estrone sulphatase activity in white blood cells to monitor in vivo inhibition of steroid sulphatase activity by oestrone-3-O-sulphamate. J Steroid Biochem Mol Biol 62: 45-51, 1997.

REED MJ, PUROHIT A, WOO LW, NEWMAN SP, POTTER BV: Steroid sulfatase: molecular biology, regulation, and inhibition. Endocr Rev 26: 171-202, 2005.

SARABIA SF, RAYA JL, HOOGEVEEN RC, BRAY PF: Human platelets differentially concentrate estradiol, estrone and testosterone. J Thromb Haemost 6: 703-705, 2008.

SOLIMAN HR, DIRE D, BOUDOU P, JULIEN R, LAUNAY JM, BRERAULT JL, VILLETTE JM, FIET J: Characterization of estrone sulfatase activity in human thrombocytes. J Steroid Biochem Mol Biol 46: 215-226, 1993.

STECKELBROECK S, NASSEN A, UGELE B, LUDWIG M, WATZKA M, REISSINGER A, CLUSMANN H, LÜTJOHANN D, SIEKMANN L, KLINGMÜLLER D, HANS VH: Steroid sulfatase (STS) expression in the human temporal lobe: enzyme activity, mRNA expression and inmunohistochemistry study. J Neurochem 89: 403-417, 2004.

TAMAI I, NOZAWA T, KOSHIDA M, NEZU J, SAI Y, TSUJI A: Functional characterization of human organic anion transporting polypeptide B (OATP-B) in comparison with liver-specific OATP-C. Pharm Res 18: 1262-1269, 2001.

TRIVELI DP, KHAW KT: Dehydroepiandrosterone sulfate and mortality in elderly men and women. J Clin Endocrinol Metab 86: 4171- 4177, 2001.

UGELE B, ST-PIERRE MV, PIHUSCH M, BAHN A, HANTSCHMANN P: Characterization and identification of steroid sulfate transporters of human placenta. Am J Physiol Endocrinol Metab 284: E390-E398, 2003.

WILLIAMS MR, DAWOOD T, LING S, DAI A, LEW R, MYLES K, FUNDER JW, SUDHIR K, KOMESAROFF PA: Dehydroepiandrosterone increases endothelial cell proliferation in vitro and improves endothelial function in vivo by mechanisms independent of androgen and estrogen receptors. J Clin Endocrinol Metab 89: 4708$4715,2004$.

WILKERSON WR, SANE DC: Aging and thrombosis. Semin Thromb Hemost 28: 555- 568, 2002.

WONG CK, KEUNG WM: Daidzein sulfoconjugates are potent inhibitors of sterol sulfatase (EC3162). Biochem Biophys Res Comm 233: 579-583, 1997.

WU GJ, LEE JJ, CHOU DS, JAYAKUMAR T, HSIAO G, CHEN WF, SHEU JR: Inhibitory signaling of 17ß-estradiol in platelet activation: the pivotal role of cyclic AMP-mediated nitric oxide synthase activation. Eur $J$ Pharmacol 649: 140-149, 2010. 